\title{
A FLUIDEZ DO TERRITÓRIO: CAPITALISMO E FRONTEIRA NA OBRA DE PIERRE MONBEIG
}

\author{
THE FLUIDITY OF TERRITORY: CAPITALISM AND FRONTIER IN THE \\ WORK OF PIERRE MONBEIG
}

\section{LA FLUIDEZ DEL TERRITORIO: CAPITALISMO Y FRONTERA EN LA OBRA DE PIERRE MONBEIG}

\author{
Carlo Eugênio Nogueira \\ Professor do Departamento de Geografia e do Programa de Pós-Graduação em Geografia da Universidade \\ Federal do Espirito Santo (UFES). E-mail: carleugenio@gmail.com
}

\section{Resumo}

A partir da análise da noção de frente pioneira explicitada na obra do geógrafo francês Pierre Monbeig, entre as décadas de 1930 e 1950, busca-se avaliar a relação existente entre a expansão espacial do povoamento ocorrida no Brasil, na primeira metade do século XX, e o processo de formação territorial do país. A argumentação desenvolvida vai apontar de que maneira a descrição explicativa das áreas de movimentação de fronteiras, dinamizadas pela expansão espacial da colonização, comporta uma análise sobre o processo de construção dos sistemas de engenharia que conseguiram consolidar nexos de solidariedade entre distintos lugares do território brasileiro. Nesse movimento de dinamização das fronteiras, que impulsionou a fundação de cidades, o desmatamento de florestas e a abertura de campos de cultivo e pastos, o território ganhou fluidez, modificando sua organização espacial para se adequar às novas necessidades surgidas com a expansão do capitalismo no Brasil.

Palavras chave: frentes pioneiras, formação territorial, fronteira, Pierre Monbeig, Brasil.

\section{Abstract}

Based upon the analysis of the pioneer fringe as it is expounded in the work of French geographer Pierre Monbeig between the 1930's and the 1950's, we intend to analyze the relation between the spatial expansion of Brazilian settlement, occurred in the first half of the twentieth century, and the process of territorial formation. The argumentation developed will point out in what ways the descriptive explanation of the moving frontier, dynamized by the spatial expansion of colonization, reveals an interpretation about the construction of engineering systems planned to consolidate spatial relations among different places in the Brazilian territory. In this movement to dynamize the borders, which impelled, for its turn, the foundation of cities, the deforestation and the formation of agriculture fields and pastures, the territory gained fluidity, changing its spatial organization to ensure the territorial integration necessary for the expansion of capitalism in Brazil.

Keywords: pioneer fringes, territorial formation, frontier, Pierre Monbeig, Brazil. 


\section{Resumen}

Partiendo del concepto de frente pionera desarrollado por el geógrafo francés Pierre Monbeig entre 1930 y 1950, nuestro objetivo es analizar la relación entre expansión espacial del poblamiento y formación territorial de Brasil, en la primera mitad del siglo XX. La argumentación desarrollada señalará cómo la descripción explicativa de las áreas de movimiento de fronteras, dinamizadas por la expansión espacial de la colonización, admite un análisis de la implementación de los sistemas de ingeniería que consolidaran las relaciones entre distintos lugares del territorio brasileño. En este movimiento para dinamizar las fronteras, que impulsó la fundación de ciudades, la deforestación de bosques y la apertura de campos de cultivo y pastos, el territorio ganó fluidez, modificando su organización espacial para adaptarse a las nuevas necesidades que surgieron con la expansión del capitalismo en Brasil.

Palabras clave: frentes pioneras, formación territorial, frontera, Pierre Monbeig, Brasil.

D 


\section{Introdução}

No Brasil da primeira metade do século XX, a questão da expansão territorial da sociedade sobre as terras formalmente sob o controle do Estado, que atrelava vulgarmente a compreensão do processo de formação do país à integração do território, aparecia como tema polarizador de boa parte dos debates encetados entre os partícipes do chamado pensamento político-social. Nessa direção, não surpreende que também nos registros dos geógrafos que se dedicaram à análise da difusão espacial do povoamento do Brasil, sobretudo após a institucionalização acadêmica do campo disciplinar, o imperialismo interiorizado exercido nas áreas qualificadas como "sertões" tenha se tornado ponto consensual para as discussões e propostas de ação (NOGUEIRA, 2013).

Nas próximas linhas, essa circunstância será tomada como pano de fundo para se efetuar uma análise a respeito da noção de "frente" ou "franja pioneira", conforme explicitada na obra do geógrafo francês Pierre Monbeig, entre as décadas de 1930 e 1950. Em detalhe, objetiva-se indicar, por meio da leitura de um conjunto de textos selecionados desse geógrafo francês, de que maneira a sua descrição explicativa da chamada "marcha do café" (FRANÇA, 1960), ocorrida nas áreas da fronteira oeste de São Paulo e norte do Paraná, pode ser considerada um esforço de construção de uma análise especificamente geográfica sobre a consolidação do capitalismo no Brasil.

Tomando como referência uma definição do conceito de formação territorial que concebe o território simultaneamente como materialidade e representação, relacionando o processo de sua efetiva ocupação material com os discursos e projetos que o têm como objeto (MORAES, 2014), defende-se a hipótese de que Monbeig, por meio de suas análises sobre o Brasil, vislumbra o processo de construção dos sistemas de engenharia que estavam a tecer nexos de solidariedade espacial (SANTOS, 1997) entre distintos pontos do território brasileiro. Tais sistemas de engenharia, traduzidos nas formas de ferrovias, rodovias, fábricas ou mesmo de cidades surgidas da noite para o dia, na febre da conquista de terras, expressam materialmente o processo de territorialização do capital que, no início do século XX, comandava a nova dinâmica da produção do espaço colocada ao país.

\section{Formação territorial e conquista de terras no Brasil}

A respeito do processo brasileiro de formação territorial, parte-se de uma argumentação que reconhece a existência de uma espécie de razão de Estado, presente sobretudo nos países de formação colonial, que costuma identificar o Brasil ao seu território, e não à 
sua sociedade (MORAES, 2002). Reverberando uma visão instrumental dos segmentos populares e servindo como justificativa à elaboração de diferentes estratégias de apropriação territorial, essa concepção espacialista do Brasil, continuamente reposta em formulações diversas desde ao menos meados do século XIX, enraíza-se na ideia de construção do país, mote ideológico que passa a informar um projeto nacional imiscuído em uma ótica geopolítica (MORAES, 2011).

Nesses parâmetros, em uma primeira consideração do fenômeno pioneiro, no Brasil, a análise de diferentes autores e perspectivas nos deixaria inclinados a atestar a existência de um juízo comum, bem ou mal generalizado pelas classes letradas, até meados do século XX, segundo o qual a explicação das particularidades nacionais aparece como decorrência do relacionamento íntimo entre a conquista de novas terras, o avanço do povoamento, a busca do desenvolvimento econômico e a consolidação da identidade nacional. Nessa operação, insiste-se em se estabelecer um vínculo de cunho essencialista entre o conhecimento sistemático do território, o domínio da natureza tropical, a exploração produtiva de seus recursos e a origem da singularidade do povo brasileiro.

Tendo como referência o que era produzido dentro do pensamento político-social brasileiro desse período, o conjunto dos estudos geográficos sobre as frentes pioneiras pode ser considerado como uma modalidade discursiva que se utiliza preponderantemente de conceitos de base espacial, tais como fronteira, paisagem e região, para elaborar explicações sobre o Brasil. No geral, os estudos geográficos sobre o pioneirismo se preocupariam com questões atinentes ao espraiamento espacial do povoamento, à exploração econômica dos recursos naturais e à integração do território, distinguindo-se em relação a outros tipos de registros que, igualmente, viam o espaço como um dos elementos constitutivos do processo de consolidação dos Estados-nacionais, mas que o valorizavam a partir de aspectos como o identitário ou o cultural (MAIA, 2008; OLIVEIRA, 2000).

Um ponto em aberto no tratamento geográfico das frentes pioneiras é a sua relação ambígua com a chamada "tese da fronteira". Enunciada, primeiramente, pelo historiador norte-americano Frederick Jackson Turner, em 1893, e, desde então, tomada em consideração por diversos autores, a chamada frontier thesis associa a fronteira a uma extensão variável de terras onde ocorreriam a expansão e a consequente perenização da colonização. Em outras palavras, a fronteira serviria para designar o avanço civilizatório da população americana por sobre espaços considerados vazios, o que acaba por conferir uma centralidade à expansão territorial na formação da nacionalidade e na consolidação da democracia estadunidense, pois teria sido a partir da experiência social da fronteira -sempre em movimento - que

D

D Revista da Associação Nacional de Pós-graduação e Pesquisa em Geografia (Anpege).

D D p.139-168, V.15, n.27, mai./ago. 2019. 
as instituições que caracterizaram distintamente o processo americano de construção de uma identidade nacional tomaram forma. Acerca desse ponto, Lígia Osório Silva (2001) observa que, analisado de um viés histórico e historiográfico, o estudo das estratégias de colonização e povoamento, na época de Turner, não era exatamente uma novidade na Europa - novo, na realidade, era o fenômeno mais amplo de expansão de uma sociedade em movimento, que, a partir do século XIX e dos estudos de inspiração turneriana, passou a ser designado pelo conceito de fronteira.

Em uma análise das obras e autores clássicos do pensamento político-social, é comum o recurso ao conceito de fronteira como modo de se compreender as particularidades da civilização surgida nos trópicos como decorrência da mobilidade da colonização lusitana. A conquista do território e a construção da identidade brasileira, não raro, se confundem. Caso conhecido, a interpretação desenvolvida por Sérgio Buarque de Holanda, em seus estudos sobre a expansão do povoamento iniciada a partir dos núcleos situados na São Paulo colonial, pode ser tida como exemplar. Sérgio Buarque considera que a colonização do planalto paulista foi muito influenciada pelas condições desfavoráveis apresentadas pelo meio natural, que exigiram, por parte dos conquistadores europeus, adaptação ao novo espaço em que a apreensão das técnicas e dos ensinamentos dos naturais da terra foi imprescindível (HOLANDA, 1990; 1994).

A busca do caminho, que incita à experiência da fronteira (transformada, depois, num movimento de conquista dos sertões), marcaria, então, as formas de sociabilidade provisórias e itinerantes desenvolvidas, desde o século XVII, entre portugueses, negros, indígenas e a massa de descendentes mestiços que habitavam o planalto vicentino (KOK, 2004; MELLO E SOUZA, 1997). Isto quer dizer que o ajustamento do colonizador à natureza americana, facilitado pelo aprendizado das técnicas indígenas, teria sido encetado em terras futuramente paulistas com mais afinco e vigor do que em outras localidades da América portuguesa, adensando o caráter singular do novo colono luso-brasileiro que se formava nos trópicos, em oposição ao velho colonizador europeu.

A releitura americana do legado ibérico efetuada por Sérgio Buarque, em livros como Monções e Caminhos e fronteiras, que se valem de uma explicação situacional que confere papel ativo à singularidade do espaço do Novo Mundo na transformação dos valores e instituições transladados da Europa pelos colonizadores, foi já notada por Robert Wegner (2000), que avalia a possibilidade de se analisar a importância da fronteira na obra do historiador paulista a partir de uma chave interpretativa de inspiração turneriana. Para Wegner, é produtivo ler os escritos de Holanda que tratam do bandeirismo e da conquista 
do oeste a partir de certos aspectos presentes no núcleo da tese de Turner, principalmente a influência transformadora recebida pelos colonizadores no contato com os indígenas e com um meio geográfico diverso. Este arranjo explicativo proposto por Wegner permite vislumbrar como Sérgio Buarque pensou a dinâmica de americanização proporcionada pela fronteira mediante a relação engendrada entre o espaço tropical, a tradição ibérica e a modernização imposta a esta tradição no processo de expansão das fronteiras continentais luso-americanas.

No caso dos trabalhos publicados por Monbeig, durante a sua estadia no Brasil (1935-46), ${ }^{1}$ que não deixa de remeter a origem do movimento de conquista de terras ligado à expansão do café a um passado bandeirante tantas vezes glorificado em São Paulo, o fenômeno descrito pelas frentes pioneiras parece indicar, em certo sentido, uma forma de compreensão da maneira como o capitalismo se desenvolveu no Brasil. O enquadramento por ele construído se fundamenta em uma chave interpretativa que congrega simultaneamente o espraiamento espacial da ocupação do território e a integração dos distintos focos de povoamento do então designado "arquipélago brasileiro". Como resultado, a expansão dos fluxos internos (representada pela circulação de mercadorias, pessoas, ordens e ideias) é compreendida de maneira conjugada à organização de uma infraestrutura de comunicações compatível com as necessidades de deslocamento experimentadas pela economia do país à época. Desse modo, pode-se mesmo vislumbrar uma incipiente preocupação desse geógrafo francês com o papel do Estado como veículo de difusão das próteses territoriais que garantiriam a fluidez interna e a consequente modernização do território brasileiro.

Esse entendimento ajuda a revelar uma face da dinâmica espacial, no Brasil do século $\mathrm{XX}$, sobretudo, se tivermos em conta o exame das ações de incentivo à economia propostas entre 1930 e 1960. Com efeito, o avanço da modernização do Brasil, durante este período, marcado pela ascensão do nacional-desenvolvimentismo, acentua a formação de paisagens heterogêneas, criadas pela associação existente entre a expansão de produtos agrícolas de exportação (como o café e o algodão), a diversificação do parque industrial do país e o avanço da urbanização.

Seguindo, neste ponto, as pistas deixadas por Antônio Carlos Robert Moraes, que esquadrinha o tratamento do conceito de território na obra de Milton Santos, podemos dizer que, conciliando-se com as modificações de cunho epistemológico pelas quais passava a

\footnotetext{
O geógrafo francês Pierre Monbeig (1908-1987) ocupou a cátedra de Geografia da antiga Faculdade de Filosofia, Ciências e Letras da Universidade de São Paulo (FFCL/USP), entre 1935 e 1946. É, reconhecidamente, um dos principais nomes do processo de institucionalização dessa disciplina no Brasil, formando uma geração de discípulos, em São Paulo, e trabalhando ativamente na consolidação da Associação de Geógrafos Brasileiros (AGB), entidade que presidiu durante todo o período em que esteve no país.
}

D

D Revista da Associação Nacional de Pós-graduação e Pesquisa em Geografia (Anpege).

D D p.139-168, V.15, n.27, mai./ago. 2019. 
geografia, o tema da modernização do território, associado à questão da integração territorial, adquire contornos nítidos nos trabalhos do referido intelectual baiano elaborados entre o final da década de 1960 e o início de 1970 (MORAES, 2013). Por exemplo, no livro A urbanização desigual, lançado originalmente em francês, em 1971, Milton Santos compara a evolução urbana dos países industrializados com o caso dos países subdesenvolvidos. Em sua explicação, este geógrafo aponta que a fluidez experimentada pelos fluxos de bens e capitais, que caracterizaria os espaços urbanos nos países industrializados, se torna, quando ausente, uma qualidade distintiva dos espaços subdesenvolvidos. Nesta explicação, Milton elege esta qualidade como um fator explicativo da macrocefalia urbana dos países periféricos, que seria exatamente "o reflexo da não fluidez do espaço e de sua desarticulação" (SANTOS, 2010, p. 128).

Os países subdesenvolvidos, como ponto em comum, teriam, então, que avaliar a necessidade de construção de uma infraestrutura de equipamentos específicos, como estradas, portos e aeroportos, que garantissem a circulação interna dentro de seus territórios e respondessem às condições de modernização da economia:

Enquanto a cidade dos países industrializados é parte integrante de um território que mais ou menos a gerou e com o qual viveu, em constantes inter-relações, a mesma aventura histórica e econômica, a cidade dos países subdesenvolvidos aparece muitas vezes como um corpo estranho, alógeno, inserido em um meio com o qual estabelece relações descontínuas no espaço e no tempo. A não integração do território, impedindo a livre circulação dos elementos da economia (homens, bens, capitais), freia, por si só, o desenvolvimento. É por isso que se pode dizer que a cidade dos países subdesenvolvidos se lança à conquista do espaço a partir de duas verdadeiras alienações: a cidade mesma nasce para servir a interesses distantes e, por outro lado, sua zona de influência é, muitas vezes, um desses "espaços derivados", cuja vida depende, em grande parte, de fatores externos [...]. Dessa forma, a ausência de ligações fáceis entre as diferentes partes do país constitui fator de atraso, como se pode ver nas dificuldades encontradas pelo Brasil por ocasião de seu desenvolvimento industrial. O país teve de fazer face aos problemas de transportes e serviços de base, anteriormente organizados em função dos interesses da economia de exportação e, por isso, não adaptados para servir um mercado interno (SANTOS, 2010, pp. 109-110).

O encaminhamento dado por Milton Santos à questão da urbanização pode se constituir como uma referência na compreensão do resultado do processo da expansão pioneira que fora avaliado por Monbeig, anos antes. De fato, a preocupação com os temas da integração e da dispersão, que marca o pensamento e a realidade brasileira, inspirou os trabalhos de muitos geógrafos que se dispuseram a fornecer a sua contribuição para o entendimento do país. Tais temas aparecem no horizonte das obras daqueles que mais detidamente analisaram as franjas pioneiras sob a forma de análises acerca da infraestrutura 
de transportes que facilitaria a chegada (ou a manutenção) da população e o escoamento das mercadorias produzidas nas novas áreas produtivas integradas ao espaço econômico do país. Assim, o movimento de incorporação de novas terras ao espaço econômico brasileiro, executado por meio da abertura de amplas áreas dedicadas ao cultivo de produtos voltados para o comércio internacional, permite que identifiquemos um processo de acumulação primitiva mediado pela exploração e valorização destas novas terras, em uma expansão territorial do capital que logrou transformar espaços considerados vazios em áreas economicamente ativas do território nacional. ${ }^{2}$

A definição do conceito de franja pioneira proposta por Pierre Monbeig costuma caracterizar o fenômeno pioneiro como homônimo do avanço de um grupo humano que se encontraria num "estágio superior de civilização" por espaços tidos como vazios, num movimento de colonização e povoamento que integra novas áreas a um dado espaço econômico catalisando a formação de identidades nacionais. Dito de outro modo, define-se o movimento pioneiro como um processo de expansão do ecúmeno. Este termo grego, adaptado da biologia darwinista, era utilizado em alusão às áreas do globo terrestre consideradas capazes de fornecer suporte para o desenvolvimento da vida humana. Entre o final do século XIX e o início do século XX, o ecúmeno se transformou numa noção consagrada das geografias de sotaque francês ou alemão: em uma palavra, como queria Maximilien Sorre (1955), o ecúmeno seria sinônimo da ideia de espaço habitado pelo homem. ${ }^{3}$

Seguindo, pois, uma tradição há muito presente na geografia, as regiões pioneiras definir-se-iam como as áreas da superfície terrestre em via de ocupação pelos grupos humanos, que, ao conquistá-las, libertam-nas da dominação dos meios naturais e as incorporam ao ecúmeno. Além disso, as regiões pioneiras do globo terrestre se apresentam como palcos onde se assiste ao desenrolar de contatos e conflitos entre sociedades que apresentam níveis de desenvolvimento técnico, econômico, político e demográfico desiguais. As frentes pioneiras podem ser vistas, portanto, como resultantes de um movimento de fluxo contínuo que modifica não apenas as paisagens naturais e culturais, mas, igualmente, as populações das áreas apropriadas em sua dinâmica de expansão.

\footnotetext{
Sobre a identificação do movimento de apropriação territorial com o momento da acumulação primitiva no processo de expansão do capitalismo, no Brasil, vide: Foweraker (1981); Martins (1975; 2009) e Velho (1972; 1979).

3 "L’extension de l’œkoumène continue de s’accomplir par la pénétration de groupes humains pionniers dans les secteurs de la planète encore peu habités. Une région pionnière peut se définir comme l'un des ces secteurs en cours d'incorporation à l'œkoumène [...] la région pionnière est le théâtre de contacts et de conflits entre des sociétés humaines techniquement, économiquement, démographiquement et politiquement inégales. On y assiste à la disparition du paysage naturel qui, sous l'action des pionniers, fait place à un paysage humanisé : naissance et formation de campagnes, fondation et croissance de villes, construction d'un réseau de communications. En même temps se constituent de nouveaux foyers de production, de nouveaux courants déchanges, des régions humaines qui oblitèrent les cadres naturels antérieurs, des sociétés originales par leur composition ethnique et démographique autant que par leurs modes de penser" (MONBEIG, 1966, p. 974).
}

D 
Há, então, como pano de fundo da dinâmica posta pelas frentes pioneiras, um desvelo com a dominação de espaços e homens, que se põem, ambos, à disposição das vontades daqueles que controlam o movimento. O saliente aspecto de luta entre os homens e o meio natural presente nessa definição se traduz no processo de transformação de paisagens naturais em paisagens humanizadas, que resulta na fundação de cidades, no surgimento de novos campos de cultivo e na conformação de uma rede de caminhos. A definição das franjas pioneiras como uma zona de limites imprecisos que separa a "natureza bruta" e os espaços naturais apropriados e conquistados pela "civilização" - para nos remetermos aos vocábulos de uso corrente na época - imprime a este termo um sentido de dominação de povos e terras que recoloca a questão da subordinação de grupos considerados inferiores ou primitivos (BOWMAN, 1931; 1937). Esta antropomorfização dominadora do espaço engendrada por uma economia estruturalmente exógena, que dá origem aos "espaços derivados" notados por Milton Santos, se coloca, então, como um aspecto comum a todas as regiões pioneiras ao redor do mundo.

Cumpre, portanto, asseverar que, do ponto de vista da formação territorial, o fenômeno do pioneirismo brasileiro se define, na obra de Monbeig, como o avanço do povoamento impulsionado por uma colonização de base eminentemente agrária sobre áreas pouco ou nada habitadas. Nesta definição, Monbeig identificava, com frequência, entre os sujeitos que pretendiam controlar ou comandar a direção de tais movimentos expansivos - em geral, proprietários de terras, empresas ligadas à colonização e à exploração agrícola, ou mesmo órgãos ligados ao Estado -, a tentativa de qualificar as áreas de interesse para a colonização como "espaços vazios".

Essa maneira de conceber o espaço pioneiro implicava no reconhecimento não apenas da aptidão real ou sugerida de tais áreas para a implantação de projetos de colonização, mas, sobretudo, na constatação da disponibilidade das terras ainda não incorporadas política e economicamente à órbita de atuação do Estado para a fixação populacional. Ao fim e ao cabo, tal posição, constantemente reiterada, revela a invisibilidade dos habitantes que viviam nos espaços fronteiriços, antes do início do processo de ocupação, para aqueles que estavam promovendo a ocupação. Com efeito, os povos indígenas, os posseiros e os pequenos agricultores expulsos de suas terras eram, via de regra, concebidos como portadores de técnicas primitivas e os principais símbolos do atraso que se queria superar.

\section{O pioneirismo segundo Pierre Monbeig}

Postas as linhas gerais do que se pode compreender como o fenômeno do pioneirismo, comentaremos alguns escritos de Pierre Monbeig que tratam das frentes pioneiras, devendo- 
se recordar, primeiramente, que os livros que ele publicou sobre a realidade brasileira abarcam, grosso modo, os mais representativos artigos escritos durante sua longa estadia no Brasil. Isto facilitou a realização de nossa leitura, uma vez que os livros fornecem uma periodização que, por evidente, é bem ou mal aceita. Além do mais, essa divisão cronológica das leituras, conquanto limite o material avaliado, serve também como um guia, uma vez que cada escrito fica, assim, mais preso ao contexto da época em que foi redigido. Esta postura ajuda a levar em consideração o processo de amadurecimento de Monbeig em relação a certos temas, bem como a apreciar sua proximidade com teorias e autores que, àquele momento específico, se faziam mais presentes em sua prática científica.

A primeira obra de Monbeig editada no Brasil, intitulada Ensaios de geografia humana brasileira, foi publicada em 1940, e congrega os primeiros artigos escritos por este autor ao chegar ao país. Em conjunto, os textos reunidos nos Ensaios permitem observar a maneira pela qual o recém-chegado professor aborda a realidade que irá estudar. Problemáticas então em voga na geografia, como os movimentos migratórios vinculados ao superpovoamento e a questão do surgimento do pioneirismo à escala do mundo, que relacionam a mobilidade de um excedente demográfico com a conquista e a valorização de terras consideradas vazias, são exemplarmente observadas em território paulista. Na verdade, Monbeig surpreende tais fenômenos no exato momento em que eles se desenvolvem, tomando a realidade paulista como "laboratório" e elegendo-a como seu terrain.

O segundo livro de Monbeig que trata mais detidamente do fenômeno do pioneirismo é sua tese de doutoramento, redigida ao longo da década de 1940 e originalmente apresentada, em 1950, na Universidade de Paris, sob o título Marche de peuplement et pionniers de São Paulo. Publicada em livro no ano de 1952, com o título Pionniers et planteurs de São Paulo, ela foi traduzida para o português por dois de seus ex-alunos, Ary França e Raul de Andrada e Silva, somente em 1984 - demora esta que não deixa de ser intrigante, haja vista a penetração e a influência desse autor na geografia brasileira. De todo modo, a obra Pioneiros e fazendeiros é um registro fiel da maturação do trabalho de pesquisa didático e científico desenvolvido pelo professor Monbeig, durante sua estadia em São Paulo. Em verdade, este livro tem até mesmo uma faceta de trabalho coletivo, uma vez que a presença de estudantes e de outros professores que gravitavam próximos à cadeira de Geografia Humana da Universidade de São Paulo (USP) era constante nas viagens de campo empreendidas.

Nessa obra, a expansão do povoamento catalisada pelo avanço do café e do algodão nas zonas pioneiras dos planaltos ocidentais paulistas e do norte paranaense - planaltos estes vistos como mera continuação do movimento animado pelas referidas zonas pioneiras

D

D Revista da Associação Nacional de Pós-graduação e Pesquisa em Geografia (Anpege).

D D p.139-168, V.15, n.27, mai./ago. 2019. 
- recebe um tratamento detalhado que descreve as fases da vaga pioneira em sua infatigável marcha a partir de dois prismas. Por um lado, as cidades, que se sucedem ao longo das vias férreas como "contas de um rosário", testemunhando os ritmos diversos de um avanço progressivo que as circunstâncias políticas e econômicas mundiais concorrem para acelerar ou retardar, mas não para impedir. Por outro lado, as paisagens que, em sua fisionomia e dinâmica, expressavam, tais como elas então se apresentavam, as marcas e as lembranças de conjunturas históricas que não desapareciam de todo, com a progressão do povoamento e o seu arraigamento.

Por fim, o livro Novos estudos de geografia humana brasileira, publicado em 1957, é, em muitos aspectos, parecido com aquele publicado em 1940, congregando textos esparsos já saídos no Brasil e incluindo traduções de artigos publicados originalmente em periódicos estrangeiros. De maneira um pouco distinta da coletânea anterior, contudo, este livro guarda o mérito de reunir em um só volume escritos de uma fase intelectualmente mais madura desse autor, que, de volta à França, procede a uma sorte de reavaliação de seus estudos precedentes sobre o pioneirismo, indicando novos ângulos de observação deste fenômeno ou mesmo alterando juízos e posições defendidos anteriormente.

Exemplificando a filiação metodológica de Monbeig aos cânones da geografia regional francesa, os textos a respeito do pioneirismo saídos nos Ensaios e nos Novos estudos seguem, no geral, um padrão de exposição que não se distancia sobremaneira dos modelos fornecidos pelas teses de Raoul Blanchard (1906) sobre Flandres, ou, e principalmente, do trabalho de Albert Demangeon (1905) sobre a Picardia. Ambos são tidos, numa visão retrospectiva, como dois dos trabalhos mais influentes, nos anos subsequentes, pois estabeleceram um modelo de apresentação dos assuntos no qual o tratamento do objeto é dividido em duas partes distintas: uma, preocupada com os aspectos físicos (com destaque para os solos, o relevo, a rede hidrográfica e a vegetação), e a outra parte, dedicada aos aspectos humanos. A depender da ênfase do autor, a seção dedicada aos aspectos humanos poderia ser subdividida em duas grandes áreas: uma área, ligada à economia regional, tratando da agricultura, das indústrias e das vias de comunicação que servem o comércio regional, e a outra área, mais afeita ao histórico de ocupação, que se detém nas etapas do povoamento, no surgimento das cidades, na repartição da população, na descrição dos habitat e nas divisões das propriedades rurais (WOLF, 2005).

A preocupação de Monbeig com uma série de temas considerados de tratamento incontornável em qualquer inquérito de campo digno deste nome, como a colonização, as vias de comunicação, o povoamento, as migrações, os tipos de habitação, os habitat e as 
transmutações das paisagens urbanas e rurais, seguia, em geral, as indicações pedagógicas de Albert Demangeon, não se afastando do modelo de escrita científica desenvolvida para a geografia pelos cânones da escola de Vidal de La Blache (NOGUEIRA, 2015). De modo representativo, também a preocupação com os aspectos naturais mais ligados à geografia física, que serviam de base para o entendimento dos aspectos humanos, eram descritos conjuntamente com os fenômenos sociais. Tal ocorria porque se tratava de uma geografia física voltada para a exploração humana, já que a valorização positiva ou não de uma dada condição natural seria feita sempre a partir das possibilidades de seu aproveitamento pelos grupos humanos.

Vejamos, mais detidamente, dois textos de Monbeig, quais sejam: "A zona pioneira do Norte Paraná" (1935) e "As zonas pioneiras do Estado de São Paulo" (1937). ${ }^{4}$ Explicitadas as influências básicas deste autor, não é de se estranhar que os capítulos dos Ensaios que tratam do fenômeno do pioneirismo sigam, basicamente, o mesmo caminho já trilhado por Demangeon: primeiramente, alguns parágrafos apresentando o assunto de que irá tratar, bem como algumas referências a autores que já produziram estudos na temática geral a ser desenvolvida, tratando de problemas similares na mesma região-objeto ou em outras áreas. Depois, como não poderia deixar de ser, passa-se a uma localização geral da região, ao que se segue uma rápida caracterização de seu quadro físico, com especial atenção à estrutura geológica, aos solos, à rede hidrográfica, ao modelado do relevo e à vegetação neste momento, normalmente, são apresentados a documentação geográfica e os dados estatísticos porventura existentes.

Terminada essa introdução-padrão, Monbeig segue sua exposição, em Ensaios, na busca de uma recomposição histórica da região, tentando localizá-la dentro do quadro mais amplo da qual ela faz parte. Em outras palavras, após descrever o sítio, tenta compreender a situação da região analisada, compondo um quadro que abrange uma escala um pouco mais ampla. Posteriormente, passa a descrever a localização das estradas de ferro e de rodagem, assim como a relação destas com a origem das aglomerações humanas, que, nos planaltos ocidentais paulistas, alongavam-se, acompanhando os espigões e os divisores d'água "à moda das vias romanas da Gália", como diz, a certa altura, num rompante de observador europeu desconcertado tentando se apegar a uma referência conhecida.

Seu próximo passo, invariavelmente, é a descrição histórica de como vieram a se formar as propriedades rurais e os patrimônio urbanos, ou seja, importa a questão do

\footnotetext{
4 Ambos foram escritos originalmente como artigos, e, depois, republicados como capítulos, nos Ensaios. O primeiro, de 1935, foi publicado na revista Geografia (AGB, ano I, n. 3, São Paulo), e o segundo, nos Annales d'Histoire économique et sociale (année IX, n. 46, juillet 1937).
}

D D D Revista da Associação Nacional de Pós-graduação e Pesquisa em Geografia (Anpege).

D D p.139-168, V.15, n.27, mai./ago. 2019. 
desbravamento das áreas florestais (vale dizer, da derrubada da mata e da formação das fazendas), uma vez que "através de toda a zona pioneira, a colonização encontra sua origem na especulação da venda de terras, especulação que toma formas diversas e, por isso mesmo, imprime variantes sensíveis a esta colonização" (MONBEIG, 1940, p. 25). Embora não toque diretamente no tema da concentração de terras, visto que não discute a questão da formação da propriedade privada nas zonas pioneiras, Monbeig reconhece, em diversas passagens, a ação de especuladores e grileiros no açambarcamento de terras que deu origem aos grandes domínios agrários observados por ele, no início do século XX.

Sendo assim, de forma indireta, a questão da terra assume, em seus escritos, um registro intimamente imbricado com a questão da mão de obra e com os projetos oficiais de colonização, articulando a expansão do povoamento à questão da fixação do trabalhador na terra. Todavia, ao apreciar as tentativas de se elaborarem planos de colonização pelos governos federal e estadual, esse geógrafo diferencia o caso brasileiro do canadense ou americano, afirmando, de maneira surpreendente, que os planos de colonização elaborados por órgão oficiais esbarravam no fato de que, no Brasil, não haveria terras disponíveis para se implantar os projetos:

Convém sublinhar que a colonização oficial no Brasil tornou-se particularmente difícil, porque toda a terra pertencia a um proprietário particular. Os domínios da União ou dos estados eram muito limitados e as terras devolutas eram sempre as mais afastadas, de acesso difícil e condenadas por muito tempo ao isolamento. Para organizar focos de colonização, com pequenas propriedades, escolas, oficinas, direção agronômica, rodovias e ferrovias, via-se o governo na continência de comprar as terras ou contratar uma empresa privada. A situação jurídica das terras, nesse país provindo da colonização régia portuguesa, foi assim grande obstáculo à execução de um plano de colonização efetiva, cuja concepção não era estranha aos espíritos lúcidos.

No estado de São Paulo todas as terras são de propriedade particular, tanto as de florestas como as de campos. Isso se deve à legislação fundiária, ao povoamento da fase inicial e à perseverança dos grileiros. A noção de terra pertencente ao estado é tão estranha à mentalidade paulista, que foi impossível manter uma reserva florestal na serra do Diabo. No Paraná a situação é diferente e o governo do estado possui ainda grandes extensões florestais. Se, às vezes, ele mesmo criou centros de colonização, no norte do estado preferiu vender glebas a empresas de grande porte. Dessa forma, para onde quer que se dirija, o avanço paulista encontra sempre propriedades privadas. $O$ pioneiro não pode, portanto, como nos países de free land, instalar-se ao seu bel-prazer e criar amplos patrimônios, limitados apenas pelas suas possibilidades de trabalho, sem despesa e sem o risco de ser barrado pela propriedade de um vizinho (MONBEIG, 1984 [1952], pp. 160/211). 
Mesmo que se considere como inaceitável essa pretensa neutralidade do francês acerca da criação das grandes propriedades particulares a partir do patrimônio público de terras, devemos indicar que, para a maior parte dos autores que se debruçaram sobre este tema, a questão da colonização, em vez de se pautar pela necessidade da formação de núcleos fixos de colonização voltados para a manutenção dos pequenos produtores em sua própria terra, esteve sempre vinculada aos interesses imediatos dos quadros dirigentes, como banqueiros, fazendeiros e vendedores de terras. Desse modo, em boa parte dos registros do pensamento político-social que tratam do assunto, os problemas atinentes ao processo de povoamento e colonização apareciam, desde o final do século XIX, como uma questão a ser resolvida a partir das necessidades de mão de obra dos grandes fazendeiros.

Afastando-se dessa posição, Monbeig diferencia a mera exploração agrícola das terras (feita de maneira extensiva, sem preocupações com a preservação dos recursos naturais e com grandes prejuízos para o povoamento do país) da verdadeira colonização, que dizia respeito à formação de uma classe de pequenos ou médios proprietários sedentarizados à feição dos camponeses europeus. Estabelecendo diálogo com a posição expressa por Caio Prado Júnior, que, em duas conferências pronunciadas em 1946, havia tratado das políticas de povoamento e da formação da pequena propriedade rural exatamente a partir da instabilidade do homem rural brasileiro e das exigências de braços para as lavouras nas grandes propriedades exportadoras, o geógrafo francês vincula o surgimento dos pequenos domínios ao sucesso ou ao fracasso econômico das grandes explorações. ${ }^{5}$

Assim, uma colonização digna de ser reconhecida como tal só ocorreria com a fixação do trabalhador rural à terra. Caso contrário, o que haveria seria apenas uma conquista de terras tributária da mera especulação, fato cada vez mais generalizado com a valorização que conferia aos especuladores lucros inversamente proporcionais à disponibilidade de terras para serem apropriadas. Quando o espaço rareia e aumenta a procura por solos naturalmente férteis, os preços disparam e a venda de terras se torna um negócio cada vez mais procurado, sendo, pois, algo comum à zona pioneira notar que "nos últimos 15 anos, a especulação generalizou-se, a terra virgem produz lucros antes de produzir colheitas e os preços não cessam de aumentar” (MONBEIG, 1984 [1952], p. 212).

\footnotetext{
5 Os textos a que se faz referência são "Problemas de povoamento e a divisão da propriedade rural" e "A imigração brasileira no passado e no futuro", publicados por Caio Prado Jr. (1953), em seu livro A evolução política do Brasil e outros estudos. Sem se aprofundar nessa questão, basta dizer que, na época, marcada pela redemocratização do governo Dutra, a questão agrária e a discussão acerca do papel da agricultura no futuro do país ganharam forte relevo. Desse modo, os debates acerca da estrutura fundiária e a defesa das vantagens da pequena propriedade ante o latifúndio se tornaram uma opinião comum, tanto para movimentos de esquerda, quanto para certos políticos e intelectuais bem ou mal alinhados com as políticas territoriais do Estado Novo que tiveram continuidade no governo Dutra. Para uma discussão que contextualiza as discussões ocorridas ao longo da década de 1940, a partir das modificações ocorridas no fazer geográfico de Orlando Valverde, vide Adas (2006).
}

D

D Revista da Associação Nacional de Pós-graduação e Pesquisa em Geografia (Anpege).

D $D$ p.139-168, V.15, n.27, mai./ago. 2019. 
Ora, é exatamente no que diz respeito à colonização e ao efetivo povoamento de novas áreas que encontramos uma diferenciação que irá acompanhar boa parte dos desdobramentos posteriores dos escritos de Pierre Monbeig dedicados ao pioneirismo, a saber, aquela que dá relevo ao contraste entre os métodos de colonização praticados no norte do Paraná pela inglesa Companhia de Terras e os métodos empregados em São Paulo, que este geógrafo alcunha de "velho sistema paulista". O primeiro método de colonização, de cariz indiscutivelmente capitalista e moderno, trabalharia com previdência e planos pré-traçados, procurando sistematizar cientificamente aquilo que antes era feito de modo empírico. Como já se pode imaginar, esse método abre espaço para a atuação do geógrafo, visto como o profissional mais indicado para secundar, dos pontos de vista técnico e científico, os trabalhos de colonização. Por sua vez, o "velho sistema paulista" seria iniciado, na maior parte das vezes, com a posse de grandes extensões de terras por um indivíduo ou pequeno grupo familial que só irá "abrir fazendas", desfazendo-se de suas matas intocadas e retalhando-as, quando o proprietário vir a "civilização" se aproximar, ou melhor, quando as áreas de derrubadas chegarem a uma distância de 200 ou 300 quilômetros de seu domínio.

Tendo em vista o que já foi discutido, poderíamos ver, nessa diferenciação entre um tipo "moderno" de colonização e o modelo do grande fazendeiro paulista (herdeiro direto do antigo período colonial), uma discussão acerca das vias de desenvolvimento do capitalismo. Na verdade, a interpretação de Monbeig (1952) sugere que o passado colonial brasileiro, ao criar estruturas econômicas, políticas e sociais expressas na organização espacial das paisagens das grandes fazendas monoculturas, se manteve ativo mesmo em uma situação posterior, sendo, então, a realidade a ser superada pelas mudanças estruturais na economia e nas refuncionalizações do espaço construído herdado, ocorridas com a expansão das relações capitalistas.

Os resquícios desse passado colonial, que continuava a influenciar as direções tomadas pelas correntes de povoamento pioneiras, seriam visíveis nas plantações de café abandonadas e nas grandes extensões de solos desgastados. Tais aspectos decadentes da paisagem eram observados por toda a parte, e deram origem a uma expressão largamente utilizada pelos geógrafos da época para qualificar o abandono: as "capoeiras", que se referiam exatamente às paisagens humanizadas de outrora que se encontravam em via de serem retomadas pela natureza. E, mesmo nos modos de pensar dos fazendeiros, que tinham dificuldade em encarar a imigração fora da perspectiva de suas necessidades básicas de mão de obra, pode-se perceber a força com que o passado colonial se fazia presente nos novos arranjos que iam surgindo, compondo uma nova estrutura econômica e social. 
Além do mais, os elogios explícitos feitos por Monbeig à colonização efetuada pela Companhia de Terras, tomada como superior ao clássico modelo paulista exatamente por criar uma massa de pequenos e médios proprietários e não se pautar unicamente pelos interesses das classes dirigentes, tradicionalmente favoráveis à manutenção dos grandes domínios, apontam para o fato de que a generalização das relações capitalistas no campo, que perturbava os antigos acordos socialmente estabelecidos, era vista como um caminho seguro para a superação do passado colonial brasileiro. Isto é, para a superação do atraso do país, que seria conseguida somente com a introdução de novas técnicas agrárias que auxiliariam as novas formas de relacionamento entre o homem e o meio.

\section{Expansão da fronteira, urbanização e a formação de regiões}

Da parte de Monbeig, surpreende sua arguta percepção do entrelaçamento íntimo entre o desenvolvimento urbano então em marcha decisiva, pois que catalisado pela industrialização, e a existência de terras consideradas livres ou vazias. Marcada por uma constante instabilidade, é sob o signo da marcha pioneira em direção ao oeste que se engendram renovados nexos de solidariedade entre pessoas e lugares. Nesse movimento incessante, o novo e o velho se produzem mutuamente, visto que é da conquista progressiva de novas terras e gentes - estas colocadas sob a decisiva órbita de influência do capital que a esperança da riqueza inexplorada e os dissabores da decadência se interpenetram, expressando-se objetivamente na organização de paisagens urbanas e rurais. Para que se possa apreciar como o geógrafo francês compreendia esse fenômeno, voltemos nossa atenção ao modo como Monbeig equaciona o fenômeno do pioneirismo, oferecendo uma definição ampla que não esconde sua filiação ao que se convencionou chamar de Escola Francesa de Geografia:

A paisagem do Estado de São Paulo que talvez mais desconserta o recémchegado ao Brasil não é tanto a planície de bananeiras e mangues de Santos, nem a floresta de vertentes da Serra do Mar, nem tão pouco as vastas extensões plantadas de café, mas sim a paisagem que ele descobre ao acordar, depois de uma noite de trem, entrando nas regiões de derrubada [...]. Ali, uma cidade velha tem vinte, trinta anos no máximo. Deixa-se São Paulo com seus arranhacéus, sua atividade febril, atravessam-se pacatas cidades provincianas que caminham em marcha-lenta apesar de não contarem três quartos de século, e encontra-se outra animação, outra atividade nas cidades de madeira que a estrada de ferro atingiu há cinco anos, às vezes há alguns meses. É a zona pioneira, da qual Isaiah Bowman e os geógrafos americanos fizeram excelentes descrições no Canadá, Austrália, Manchúria ou extremo sul da Argentina, zona que conserva em toda parte um certo ar de família, mas revela-se também grandemente variada para quem procura mais do que uma simples impressão de viajante (MONBEIG, 1940, pp. 21-22).

D

D Revista da Associação Nacional de Pós-graduação e Pesquisa em Geografia (Anpege).

D D p.139-168, V.15, n.27, mai./ago. 2019. 
Ficam evidentes, no trecho acima citado, as particularidades que a zona pioneira paulista apresentaria quando confrontada às áreas que, se bem que localizadas em outros países e contando com climas, solos, relevo e vegetação diversos, manteriam com o caso brasileiro "um certo ar de família”. Ao considerar a expansão espacial do povoamento ocorrida no Brasil como uma manifestação regional de um fenômeno mundial, percebe-se que o fenômeno pioneiro teria características comuns que autorizariam um observador atento a enxergar as franjas pioneiras existentes na Argentina, Canadá ou Manchúria como variações ou combinações locais de um tema ou fenômeno global. Não é por outro motivo também que, no primeiro texto que escreveu após a sua chegada em São Paulo, em 1935, dedicado ao exame da zona pioneira do Norte-Paraná, Monbeig fundamenta o tratamento conjunto que irá conferir a esta área na análise dos movimentos migratórios perceptíveis em território paulista. Para ele, esta seria, como afirmamos anteriormente, referindo-nos a Londrina, "uma região que - se bem que pertença administrativamente ao estado do Paraná - não deixa de ser de fato uma região de economia paulista” (MONBEIG, 1940, p. 56).

A apreciação conjunta das zonas pioneiras de São Paulo e do Paraná, a despeito das diferenças existentes entre elas, pode ser percebida em um artigo que trata das vias de comunicação do estado de São Paulo, no qual Monbeig descreve as etapas evolutivas de um centro pioneiro originado pelo desenvolvimento de uma estrada de ferro. Neste artigo, ele chama a atenção para o incremento da especulação imobiliária e para a mudança de status dos núcleos fixos de ocupação desenvolvidos no entorno das estações, como centros urbanos que, em menos de dez anos, deixavam de ser febris "cidades pioneiras" ou "bocas do sertão", onde o afluxo de pessoas era incessante e tudo tinha um aspecto provisório, e passavam a viver no ritmo cadenciado das demais pequenas cidades interioranas do Brasil. Para Monbeig, os trilhos eram "criadores de paisagens", e, por isso, para ele, era impossível separar a análise do povoamento do histórico de construção das vias de comunicação.

Os termos utilizados por Monbeig são suficientemente claros, estabelecendo uma relação direta entre a construção das vias de comunicação, o crescimento demográfico, a conquista de novas terras agricultáveis e a alteração nas paisagens operada pelo incremento das atividades econômicas. Aliás, é forçoso reconhecer que o abastecimento de gêneros alimentícios e as possibilidades de exportação atuavam como fatores limitadores do povoamento, restringindo o raio de alcance e o poder de captura das ferrovias, que somente se expandiam quando as companhias de estradas de ferro se certificavam, indubitavelmente, do retorno financeiro e da rentabilidade do investimento. Esta circunstância torna a integração e a modernização do território, até certo ponto, efeitos colaterais do caráter capitalista do empreendimento, entrevisto na busca por áreas produtoras de mercadorias 
cujos fretes poderiam pagar a construção da infraestrutura ferroviária, objetivo maior que não lograva se esconder atrás do véu do "neutro progresso" por muito tempo.

Em resumo, vemos que o desenvolvimento geograficamente desigual engendrado nas franjas pioneiras envolve, por um lado, a existência de um surto agrícola lastreado por um produto comercial de grande penetração no mercado internacional, e, por outro lado, o desenvolvimento de centros urbanos pensados como lugares de atração da produção agrícola, uma vez que os fazendeiros-empresários (como normalmente acontecia) eram também loteadores urbanos. Para alavancar seus negócios e atrair os seus clientes (pequenos, médios ou grandes lavradores, comerciantes, profissionais liberais e demais partícipes da febre pioneira), esses empresários rurais investiam nas instalações industriais aptas a receber a produção agrícola, em cada uma das cidades pioneiras, atraindo para a sua esfera de influência a pauta produtiva semelhante que se estenderia por todas as zonas produtivas.

Logo, o desenvolvimento rural supõe o estabelecimento urbano, pois a realização da produção agrícola é mediada pelas cidades, que exercem o papel de centros de beneficiamento e carreamento de mercadorias, polarizam as áreas rurais e colocam o fruto de sua produção no circuito de reprodução ampliada do capital. Essa complementaridade entre o desenvolvimento industrial das cidades e a ampliação dos desbravamentos rurais existente nos planaltos ocidentais alia um desenvolvimento capitalista (que contava com financiamento estrangeiro) ao estreitamento dos laços de dependência entre as zonas pioneiras e os centros urbanos de comando das atividades econômicas, desenvolvendo nexos de solidariedade territorial que revelam a possibilidade de haver o que alguns autores caracterizaram como uma "transferência geográfica de valor" (SOJA, 1989).

No caso, a expansão do povoamento e da colonização na franja pioneira paulista, responsável pela formação de campos de cultivo, pastos, uma rede de cidades e de uma infraestrutura de caminhos - manifestações territorializadas da fixação geográfica de valor -, engendrou um sistema de trocas que punha áreas mais ou menos amplas polarizadas por cada uma das capitais regionais em relação com a metrópole paulistana e seu porto de escoamento. Esta circunstância, pela ação dos bancos e casas de crédito que atuavam em São Paulo e em Santos, acabava por mediar os contatos de subordinação das zonas pioneiras do Brasil com o mundo. A dinâmica própria das trocas comerciais encetadas nos planaltos ocidentais e no norte do Paraná, que envolviam gêneros de abastecimento e produtos industrializados voltados para o mercado interno, bem como produtos tropicais de exportação que o mercado internacional demandava, estabeleceu uma divisão territorial do trabalho - expressão da existência de uma hierarquia entre os lugares - que parece

D

D Revista da Associação Nacional de Pós-graduação e Pesquisa em Geografia (Anpege).

D D p.139-168, V.15, n.27, mai./ago. 2019. 
mesmo fundamentar o esboço de um processo de circulação de riquezas próximo de uma transferência geográfica de valor entre as capitais regionais, as localidades por elas influenciadas e a capital paulista.

Sendo assim, é necessário reconhecer que o objeto específico do estudo de Monbeig não é exatamente a frente pioneira, mas as paisagens humanas surgidas com o avanço das correntes de povoamento que acompanhavam a expansão das culturas de café e de algodão, uma vez que a apropriação e a exploração de terras com fins meramente especulativos, quando não eram bem sucedidas em fixar os colonos nas terras desbravadas, não criariam paisagens duradouras. É o arraigamento dos grupos humanos nos novos espaços que fornece, ao final, as bases para a construção da nova organização espacial do mundo pioneiro, uma vez que o estabelecimento de núcleos fixos de povoamento implica também na fixação de parte do valor socialmente produzido na forma de próteses territoriais. Por conseguinte, pode-se dizer que Monbeig está preocupado em observar de que modo a fixidez e a fluidez (ou o movimento) se combinam na franja pioneira, dando origem a paisagens humanas que expressam novos conteúdos a cada momento.

O complexo geográfico ${ }^{6}$ da franja pioneira, resultado da ação de uma sociedade em movimento, se define, então, pela mobilidade, mas se realiza plenamente pelo intermédio das formas espaciais imobilizadas na paisagem, em tempos distintos. Por isso, asseveramos que Monbeig percebia esse processo em seus aspectos sincrônicos e diacrônicos, pois ele sublinhava o movimento contínuo de expansão demográfica e econômica que se retroalimentava da construção de cidades, estradas e campos de cultivo, as marcas legadas pelos grupos humanos nas paisagens.

Ademais, ao descrever o processo de formação de regiões ligadas a uma rede de cidades e caminhos, mostrando de que maneira as distintas localidades da franja pioneira paulista reproduzem um relacionamento do tipo centro-periferia em variadas escalas, Monbeig parece exemplificar o padrão espacial de desenvolvimento geograficamente desigual (SMITH, 2008) que pode ser atrelado à via colonial de expansão do capitalismo

\footnotetext{
6 Por esse princípio, derivado de Vidal de La Blache e aperfeiçoado por André Cholley (que aceitou assumir a direção da tese de Monbeig, em 1947, visto que, desde a morte de Albert Demangeon, em 1940, Monbeig não possuía formalmente um orientador), um complexo geográfico seria o resultado sempre dinâmico de uma combinação dos fatores que incidem diretamente na organização das paisagens de uma região. Cholley tratou acerca das combinações geográficas em sua obra Guide de létudiant en Geographie, lançada em 1942 e reeditada, com pequenas modificações, em 1951. Nesta obra, afirmou que a geografia deveria estudar a organização do espaço, não tomando em separado apenas um dos diversos componentes da superfície terrestre, isolado analiticamente tal um "fato geográfico" sem relação com os demais fenômenos ocorrentes na superfície terrestre, mas se debruçando sobre o resultado da combinação entre eles. Assim, os geógrafos abordariam de frente a complexidade das paisagens presentes na superfície terrestre, encarando a geografia como uma disciplina de síntese, uma vez que as combinações associam esses diversos fatores numa relação dinâmica de interdependência recíproca. A esse respeito, vide Cholley (1951).
} 
no Brasil. Realmente, os chamados "ciclos econômicos" expressam bem o mecanismo de estruturação dos espaços periféricos, visto que a expansão do cultivo do café ou do algodão, por exemplo, compõe como que um mosaico de assentamentos produtivos que parece migrar dentro do território, manifestando uma espacialidade própria associada a sistemas de engenharia que tornam determinadas localizações privilegiadas para a circulação, que se orienta para fora, como uma verdadeira bacia de drenagem (KAYSER, 1968).

Sendo assim, as etapas de evolução dos centros pioneiros instáveis e transitórios, que normalmente vivenciavam períodos de fausto e riqueza, seguidos de longos anos de decadência e involução das relações econômicas, parecem demonstrar, em certos aspectos, o acerto do enquadramento da situação periférica sugerido por Armando Corrêa da Silva, num escrito atualmente esquecido pelos geógrafos, no qual observa que "desde sua origem e evolução uma região periférica tende necessariamente a passar pelas condições de isolamento, marginalização e complementaridade" (SILVA, 1978, p. 119). Dessa maneira, cada centro pioneiro saía de sua condição de isolamento ao se desenvolver e colocar outras áreas sob sua esfera de influência, passando, pois, a funcionar como uma região marginal ou complementar, a depender das necessidades e dos ritmos da economia dos lugares centrais, que condicionariam, em grande medida, o nível de desenvolvimento dos espaços incorporados.

De todo modo, no conjunto de escritos que reúne os seus estudos sobre esse tema, podemos verificar a recusa de Monbeig em utilizar o conceito de região para se referir à área por onde passaram, desde o século XIX, as movimentações pioneiras. Em seu doutoramento, talvez por imposição dos rituais de exposição de uma tese, mesmo reconhecendo as dificuldades de delimitação da superfície terrestre onde ocorria a expansão das fronteiras, aponta que a franja pioneira paulista se estendia do reverso das cuestas da depressão periférica, a leste, até as bordas do rio Paraná, na fronteira com o Mato Grosso (atual Mato Grosso do Sul), a oeste, e do rio Grande mineiro, ao norte, até o conjunto de serras e planaltos paranaenses além do rio Paranapanema, ao sul. Partindo desta grande unidade natural, que guardaria, bem ou mal, certa homogeneidade climática, de vegetação e de relevo, sendo uma área de transição entre o Brasil tropical e a faixa subtropical do Brasil meridional, Monbeig preferiu utilizar a noção de "zona", ligada ao uso econômico dado a um grupo humano para determinada área, ou mesmo o termo mais amplo de "faixa", que servia para qualificar tanto as áreas já devastadas e apropriadas pelos grupos humanos, quanto as áreas florestais deixadas intocadas na retaguarda do avanço pioneiro para uma ocupação futura.

D

D Revista da Associação Nacional de Pós-graduação e Pesquisa em Geografia (Anpege).

D D p.139-168, V.15, n.27, mai./ago. 2019. 
Como se pode depreender da leitura de seus textos, haveria, no estado de São Paulo, diferentes regiões em processo de formação dentro dos limites da zona pioneira como um todo. Pondo em relação os termos utilizados por Monbeig, teríamos o uso das noções de "zona" ou "faixa" pioneira para designar o conjunto de lugares onde o fenômeno pioneiro se realiza, isto é, para qualificar as áreas onde os desbravamentos e a exploração produtiva do solo se desenrolam. Nesse caso, uma colonização stricto sensu só ocorreria, como já dissemos, se houvesse a fixação dos trabalhadores na terra. Caso contrário, teríamos apenas o aumento da exploração especulativa do solo, visto que a "zona pioneira" seria unificada exatamente pelo impulso da colonização que qualifica decisivamente suas "paisagens" pela provisoriedade dos "desbravamentos". Internamente a este conjunto maior, encontraríamos distintas "regiões", cada qual em um estágio inicial de formação e integrada à sua "capital regional" - normalmente, o centro urbano de animação principal das atividades econômicas, como Araçatuba, Marília, Presidente Prudente ou Londrina, entre muitos outros (MONBEIG, 1952).

Outra consequência desse modo de qualificar a expansão do povoamento da sociedade pioneira paulista, buscando-se acompanhar o processo de formação de uma região a partir da observação de momentos diversos da conquista de novas áreas por uma sociedade em movimento, é a possibilidade de uma cidade ou localidade perder o seu status de pioneira. Foi este, por exemplo, o caso de Ribeirão Preto, principal núcleo urbano a polarizar a conquista do oeste paulista, no final do século XIX, mas que, no momento em que Monbeig escrevia a sua tese de doutorado, na década de 1940, não poderia mais ser considerada uma cidade pioneira. Conclui-se disto que a condição de "estar" pioneira se refere, pois, a algo transitório, parecendo mesmo se ligar mais à perenidade dos núcleos de povoamento em formação. Surpreender o histórico da ocupação produtiva e definitiva de parcelas do solo, tomadas da natureza pelos grupos humanos, equivale, então, a identificar o processo de formação de uma paisagem humanizada pelo uso de metáforas organicistas, pois o que se discute é exatamente a maturidade do povoamento de determinadas regiões contraposta à juventude ou à senilidade de outras. A condição pioneira se revela, assim, efêmera, tal como a sociedade que lhe dá origem.

As frentes pioneiras se põem, portanto, como um momento do processo de ocupação e conquista da natureza, uma etapa de instabilidade a ser superada pela consolidação das relações sociais entabuladas e pela fixação dos grupos humanos na terra, que expressaria, afinal, a consecução de um equilíbrio na relação homem-meio. Sendo, pois, moldada no processo de apropriação e conquista da natureza pelos grupos humanos, a homogeneidade regional das diversas zonas pioneiras - que é o que autorizaria, em última instância, a 
possibilidade de se indicar a existência de regiões internamente ao conjunto da franja pioneira paulista - expressaria a combinação complexa de uma miríade de fatores. Logo, a partir do destaque conferido a um fator específico, como a história, a rede de cidades e caminhos ou a economia, é possível identificar a existência de regiões humanas em formação.

A propósito, a concepção de região desenvolvida por Pierre Monbeig, em suas análises do fenômeno pioneiro, coloca em primeiro plano a preponderância dos fatores econômicos na definição dos distintos setores territorialmente separados. Desse modo, a fundação das cidades e a construção das vias de comunicação, influindo no funcionamento da economia, adquirem papel fundamental na apreciação das regiões humanas em processo de formação no Brasil, mesmo que não expressem a contento a formação de uma região exatamente conforme constava nos manuais da geografia francesa, nos quais o sentimento de pertencimento regional próprio aos termos pays e paysage dava suporte à existência de gêneros de vida típicos, resultantes de um longo processo de conquista da natureza pelos grupos humanos.

Com efeito, desde os seus primeiros escritos sobre esse tema, Monbeig afirmava que, para os paulistas, os únicos nomes de região popularmente utilizados e conhecidos eram os das estradas de ferro: "Assim a "Noroeste" designa, em linguagem comum, tanto a Estrada de Ferro Noroeste, que liga São Paulo a Mato Grosso, como o conjunto dos municípios servidos pela estrada" (MONBEIG, 1940, p. 23). Desse modo, após ter estudado diretamente no terreno um dos mais céleres processos de conquista de terras pelos grupos humanos ocorridos no Brasil, Monbeig questiona, no último capítulo do livro Pioneiros e fazendeiros, intitulado "Regiões ou redes de comunicação", se a ação humana que modificou as paisagens, nos planaltos ocidentais do oeste paulista e do norte paranaense, conseguiu formar unidades regionais reconhecíveis e observáveis no terreno. Já se teria estabelecido ali, nos lugares onde o desbravamento arrefecera e o povoamento estabilizara, um sentido de pertencimento comparável ao das regiões francesas?

Analisando, um a um, os fatores que, em hipótese, poderiam ensejar a criação de uma região bem ou mal homogênea, tais como a origem étnica dos muitos imigrantes que habitavam as diferentes zonas pioneiras, que facilitaria a formação de uma unidade cultural entre grupos mais ou menos numerosos, ou então a habitação dos pioneiros, "expressão do meio e do gênero de vida" (MONBEIG, 1984 [1952], p. 380), esse autor volta a apontar a grande confusão e as similaridades existentes entre as realidades da Alta Sorocabana, da Alta Paulista ou da zona de Londrina. Ao fazê-lo, conclui que, sem dúvida, os centros vitais de cada uma destas "regiões", cujos nomes provêm diretamente das companhias de estradas

D

D D Revista da Associação Nacional de Pós-graduação e Pesquisa em Geografia (Anpege).

D D p.139-168, V.15, n.27, mai./ago. 2019. 
de ferro, se constituem em uma referência mais próxima para os habitantes de cada uma dessas cidades. Na verdade, a população urbana dos distintos centros se mostrava mais ligada às suas realidades municipais efetivas ou, no máximo, ao espigão rodoferroviário que as une a outras localidades próximas, do que a uma suposta realidade regional, tal como entendida no mundo europeu:

Terra sem passado, não viu ainda a franja pioneira desabrocharem regiões, mas está dividida em redes de comunicação e essa divisão, que se apoia na topografia, será talvez o germe das regiões vindouras. Criam os trilhos a unidade, porque asseguram o escoamento da produção e porque o sucesso individual, tanto quanto o das empresas colonizadoras, depende da expedição fácil, contínua e regular dessa produção [...]. Até hoje é mais exato falar em regiões ferroviárias, que em regiões geográficas ou econômicas da franja pioneira. Fixar os limites dessas regiões é praticamente impossível. Ilude o paralelismo entre as grandes linhas do relevo e o traçado das ferrovias [...]. As ferrovias teriam, pois, transformado cada planalto numa espécie de bacia da qual são elas as artérias mestras, ao passo que as estradas de rodagem, lateralmente construídas, são como afluentes que asseguram a drenagem. Desenham a rede de trilhos e os caminhos, que as completam, uma rede hidrográfica invertida (MONBEIG, 1984 [1952], p. 385).

Como é facilmente perceptível, a questão da integração territorial, viabilizada pelos caminhos, estruturou uma rede de relações hierarquizadas na qual a produção e a circulação, demandando inicialmente as capitais regionais (centros locais de atração), se direcionavam invariavelmente para a capital. Os tentáculos da metrópole se faziam sentir até em áreas muito distantes, concentrando em sua esfera de controle e influência tanto o comércio interno (seja de gêneros alimentícios ou de matérias-primas de origem agrária produzidos na fronteira), que buscava o crescente parque industrial ou o mercado de sua população sempre em via de aumentar, quanto o comércio de exportação, que São Paulo monopolizava por sua atuação conjunta com o porto de Santos. Esta situação, por sua vez, dificultava o surgimento de quadros regionais fixos dentro da área de atuação de cada uma das ferrovias. Isto porque as disputas entre as diferentes companhias fazia da extensão da área de influência de cada uma das empresas de estradas de ferro uma função de uma série de fatores, como a distância de seus terminais em relação à capital e Santos, a capacidade de transporte dos trens e a organização técnica dos armazéns e postos de estocagem, que influíam mais do que a topografia ou mesmo a legislação no sucesso pela conquista do privilégio de exploração de uma determinada área.

A identificação do único sentimento regional intuído nas zonas pioneiras com um sentimento de classe comum apenas entre fazendeiros e comerciantes é bem representativa do 
caráter mercantil da expansão pioneira. ${ }^{7}$ Compreendida como uma modalidade da expansão territorial do capital, a frente pioneira, conforme o que Monbeig indicou, realmente tornaria solidários os principais agentes desta expansão: os fazendeiros, grandes comerciantes e negociantes de terras, que veriam na fundação das cidades, na construção de ferrovias e de rodovias e na exploração dos solos, a formação de um traço comum a unificar todas as zonas, a saber, o desejo do enriquecimento rápido e do lucro imediato.

A diferenciação entre os interesses de fazendeiros e comerciantes com a realidade dos pequenos pioneiros e sitiantes, contudo, mostra novamente a fixação dos grupos humanos nos terrenos como a questão básica a ser resolvida para a estabilização do povoamento do mundo pioneiro. As ideias conjuntas de harmonia e adaptação aos meios naturais, intrínsecas ao entendimento do gênero de vida, nos escritos de Vidal de La Blache, se colocam aqui num arranjo explicativo sugestivo, indicando que, numa sociedade em movimento, em que tudo é itinerante e provisório, a dificuldade de se forjar uma identidade regional próxima daquela descrita nas campanhas francesas acompanha as dificuldades encontradas pelos grupos sociais de se manterem enraizados num dado espaço. Contudo, o orgulho municipal a que Monbeig alude, ainda que não possa ser tomado como a base para a formação de regiões, demonstra as possibilidades colocadas pelas formas mais estáveis de ocupação do solo.

\section{Considerações finais}

Como um todo, a partir de cada um dos escritos que vimos comentando neste artigo, tentamos evidenciar os traços básicos da prática científica de Pierre Monbeig, durante sua estadia na Universidade de São Paulo, entre as décadas de 1930 e 1940. Tendo em vista a conjuntura da expansão mundial do capitalismo e do capital, no início do século XX, dentro da qual o incremento do avanço pioneiro paulista é uma manifestação contextualmente adequada, pode-se perceber, com Milton Santos, que a ideia do desenvolvimento geograficamente desigual, prefigurada nas diferentes paisagens surgidas do contraste entre as áreas agrícolas dinamizadas pelos pioneiros, dos centros urbanos que se dinamizavam e do incremento demográfico e industrial da capital paulista, ganha um novo alcance com a crescente mundialização da economia.

\footnotetext{
"O pequeno pioneiro passa da tentação dos grandes espaços ao orgulho municipal. Só para os fazendeiros e os comerciantes, cujos interesses materiais os tornam solidários com a ferrovia, são providos de sentidos os nomes de regiões. Estão eles em relações constantes com a estrada de ferro: pedem-lhe melhores tarifas, vagões mais numerosos, horários mais cômodos; seguem com atenção os progressos dela, que são também os deles. Deve-se reconhecer que tudo isso era muito distante para o sitiante. Fica-se inclinado a ver no sentimento regional, tal como se manifesta atualmente a expressão de interesses comuns de classe. Nada há que incita o sitiante à solidariedade regional, pois a sua fixação é temporária e os interesses, como as dívidas, são de curto prazo" (MONBEIG, 1984 [1952], p. 387).
}

D

D Revista da Associação Nacional de Pós-graduação e Pesquisa em Geografia (Anpege).

D D p.139-168, V.15, n.27, mai./ago. 2019. 
A partir do exame do caso paulista, é possível intuir o modo de propagação dos modernos processos de produção, que, a partir de então, vão se espalhando diferencialmente por todo o globo, e se fixam de forma concentrada em variados pontos da superfície terrestre, precipitando uma intensa especialização dos lugares (SANTOS, 1988). Uma tal especialização do processo de produção do espaço, percebida na coexistência de paisagens pretéritas, que respondiam a um arranjo surgido numa conjuntura histórica de um passado mais ou menos recente, com paisagens modernas, dinamizadas pelos processos urbanoindustriais mais atualizados do momento, é uma chave interpretativa frutífera para se compreender as contradições estruturais que opunham as "zonas velhas" da expansão cafeeira (organizadas, ainda no século XIX, sob o regime escravista) às "zonas novas" das frentes pioneiras, surgidas em meados do século XX. Uma avaliação pormenorizada destas últimas, que eram financiadas como um negócio de base capitalista, abre possibilidade para que esse processo possa ser interpretado a partir da concepção que toma o espaço como resultado de uma "acumulação desigual de tempos" (SANTOS, 1997).

Ora, no primeiro parágrafo da introdução de seu livro sobre o mundo pioneiro paulista, o geógrafo francês focalizado em nossa análise já alertara para o entrelaçamento de temporalidades diversas engendradas pela expansão do povoamento, nas áreas de fronteira (SALGUEIRO, 2006). No caso, o movimento migratório, por incessante, integrava constantemente zonas "novas" ao espaço econômico brasileiro, com o que teríamos, como consequência, polarizações entre estas áreas recém-conquistadas e as zonas “velhas", deixadas sem desenvolvimento, na retaguarda das correntes em expansão (ou por elas abandonadas, após um período de fausto a que se seguia um não menos acachapante declínio):

A atividade econômica do estado de São Paulo, centro vital da economia brasileira, recebe, da existência das zonas novas, seu impulso mais forte. $\mathrm{O}$ cultivo de terras há pouco recobertas de matas, a avançada constante dos pioneiros, a abertura de novas fazendas são fatores que agem com raro vigor sobre o conjunto da vida paulista. Toda ela se ressente do contínuo deslocamento de importante massa da população cuja instabilidade, quatro séculos após o desembarque dos primeiros portugueses, persiste como um dos seus traços fundamentais. Por outro lado, o crescimento dos bairros da capital reflete os impulsos do povoamento em tal ou qual direção; dependem as indústrias das matérias-primas fornecidas pelas regiões pioneiras, assim como da absorção dos seus produtos nos espaços recém-povoados; seus operários provêm das terras cuja decadência, em grande parte, não é senão a consequência da proximidade de vastas áreas intactas. Saindo-se da metrópole paulista e percorrendo-se os territórios de mais longa data conquistados e povoados, neles também se revela a influência das zonas novas, ainda que longínquas [...]. Por toda parte, na cidade como no campo, sente-se que nada se estabiliza, nada é definitivo, e que a economia e o povoamento se solidarizam com a marcha pioneira, que inexoravelmente arranca rumo ao oeste, a centenas de quilômetros (MONBEIG, 1984 [1952], p. 21). 
O arranjo explicativo sugerido acima adquire ainda maior significação quando percebemos que, na análise que faz da expansão pioneira para o oeste de São Paulo e o norte do Paraná, Pierre Monbeig estava a par da influência das crises mundiais do capitalismo no ritmo da apropriação de terras, catalisada pela itinerância da economia cafeeira. Em seus escritos, esse geógrafo não circunscrevia o entendimento das realidades paulista e brasileira apenas a fatores de ordem interna. Ao contrário, relacionava as modificações das paisagens rurais com a urbanização, a industrialização, o crescimento da atividade bancária e a organização de novas formas de financiamento para a economia cafeeira. Em uma palavra, apontava para a alteração da divisão social e territorial do trabalho, objetivada em um novo arranjo geográfico projetado para dar suporte às modernas atividades econômicas que se instalavam, no Brasil.

Ao comentar o jogo dos fatores econômicos na estruturação do complexo geográfico decorrente do fenômeno pioneiro paulista, mostrando as influências das diversas crises mundiais vividas pelo capitalismo na velocidade da expansão do povoamento e da colonização ocorridas em terras brasileiras, Monbeig faz menção à justaposição de escala das crises. Estas podiam ser observadas ora em escala global, com destaque para o crack da economia norte-americana, em 1929, e para as duas conflagrações mundiais, ora em escala localizada, quando as crises são entendidas como frutos das mudanças de políticas internas e das oscilações da própria produção cafeeira. As modulações ocorridas na cultura do café, umbilicalmente dependente dos humores dos mercados externos, expressam, ao fim e ao cabo, a mudança no eixo do comércio exterior do Brasil, que, ao longo do século $\mathrm{XX}$, vai se afastando dos mercados europeus para se atrelar definitivamente na esfera de influência dos Estados Unidos.

Chega-se, pois, à conclusão de que o avanço pioneiro não foi detido pela derrocada da economia mundial, ao contrário, a organização de novas fazendas, a construção de ferrovias e a fundação de cidades, com o aumento da população urbana e a aparição de um incipiente parque industrial, continuaram aceleradamente, nas quatro primeiras décadas do século XX, muito embora as crises tenham modificado permanentemente a estrutura da sociedade paulista. Isto se deu na medida em que o abandono das áreas de exploração mais antigas - que, com os solos esgotados, ficavam na retaguarda dos avanços pioneiros, eventualmente valorizando as reservas de matas deixadas desocupadas pelos proprietários em meio às áreas de derrubada - incentivava a venda de terras e a especulação imobiliária. Tal movimento indicaria a transição do antigo sistema colonial das grandes fazendas escravistas para a apropriação capitalista do espaço em um modelo já hegemonizado pelo desenvolvimento industrial e o crescimento urbano, o que influiu no fim das fazendas de tipo tradicional e contribuiu para o aumento numérico da pequena propriedade.

D

D Revista da Associação Nacional de Pós-graduação e Pesquisa em Geografia (Anpege).

D D p.139-168, V.15, n.27, mai./ago. 2019. 
Nessa passagem de um tipo a outro de paisagem pioneira, resultado das alterações conjunturais pelas quais passavam a economia e a sociedade brasileiras nesse período, a expansividade intrínseca ao funcionamento do capitalismo - seu apetite territorial resultaria em uma "homogeneização diferenciadora" dos lugares (HARVEY, 2011). Dito de outro modo, é possível identificar uma espacialidade desigual que é fruto dessa tensão entre as contraditórias tendências à concentração e à expansão geográficas, manifestação do capitalismo na diferenciação dos lugares (MORAES, 2011). Além disso, deve-se ter em conta a complexificação das operações financeiras executadas pelos bancos e casas de crédito nacionais e estrangeiras, que passam a custear as atividades agropecuárias desenvolvidas nas frentes pioneiras, cada vez mais afastadas das antigas relações pessoais que permeavam o relacionamento entre fazendeiros e colonos, nas fazendas do final do século XIX.

De mais a mais, do ponto de vista da geografia brasileira, que se consolidava como campo disciplinar autônomo, na primeira metade do século $\mathrm{XX}$, as frentes pioneiras foram enunciadas como um movimento contínuo de apropriação e de povoamento de novas terras, impulsionado, desde a sua origem, por um atividade agrária de fins comerciais, representada pelas lavouras de café e de algodão e pelo gado, e também por uma selvagem especulação imobiliária, percebida nos loteamentos de terras que originaram, de forma legal e ilegal, grandes domínios fundiários. O nexo comercial dessa corrente colonizadora é reposto e ampliado pela transformação da terra em mercadoria, que estimulava a especulação, feita, de preferência, nas proximidades de um centro urbano ou nas adjacências das estradas.

Conforme se pode depreender da argumentação desenvolvida neste artigo, o importante, para a análise geográfica das frentes pioneiras, e que sugere uma interpretação do processo de desenvolvimento do capitalismo no Brasil, não são as relações sociais engendradas nas áreas de movimentação das fronteiras, nem sequer as motivações econômicas e políticas daqueles que comandam a expansão da fronteira, embasando a dinâmica migratória, mas, sobretudo, o aspecto visível das transformações que tais fenômenos impõem à configuração territorial do país. Isto é, na análise geográfica do pioneirismo, enfoca-se apenas o resultado material que as relações sociais fixam na organização das paisagens.

Ao final, o entrelaçamento entre o crescimento urbano, a industrialização do país e a expansão de sua economia rural, que, na obra de Monbeig, aparece na análise da diferença de desenvolvimento percebida na apreciação das "zonas velhas" e das "zonas novas", parece indicar a possibilidade de se afirmar, a despeito de não ser esta a sua preocupação, que este geógrafo estava a observar e descrever in loco o movimento de desenvolvimento geograficamente desigual que marca a expansão territorial do capitalismo no Brasil. Esta afirmação, no entanto, está ainda em aberto, e, sem dúvida, indica possibilidades para o surgimento de novas pesquisas àqueles que se aventuram a perscrutar a história da geografia. 


\section{BIBLIOGRAFIA}

1. ADAS, S. O campo do geógrafo: colonização e agricultura na obra de Orlando Valverde (1917-1964). Tese (Doutorado em Geografia Humana) - DG/FFLCH/USP, São Paulo, 2006.

2. ARRIGUI, G. O longo século XX: dinheiro, poder e as origens do nosso tempo. Rio de Janeiro/São Paulo: Contraponto/Unesp, 1996.

3. BOWMAN, I. The pioneer fringe. New York: American Geographic Society, 1931.

4 . Limits of land setlement: a report on present-day possibilities. New York: Council of Foreign Relations, 1937.

5. CHOLLEY, A. Remarques sur quelques points de vue géographiques (suite). L'information géographique. Paris: Armand Colin, v. 12, n. 4, pp. 127-135, 1948.

6. __ La Géographie: guide de l'étudiant. Paris: PUF, 1951.

7. FOWERAKER, J. The struggle for land: a political economy of the pioneer frontier in Brazil from 1930 to the present day. Cambridge: Cambridge University Press, 1981.

8. FRANÇA, A. A marcha do café e as frentes pioneiras (Guia da excursão $n^{\circ} 3$ realizada por ocasião do XVIII Congresso Internacional de Geografia da UGI). Rio de Janeiro: Conselho Nacional de Geografia, 1960.

9. HARVEY, D. O enigma do capital - e as crises do capitalismo. São Paulo: Boitempo, 2011.

10. HOLANDA, S. B. Monções. São Paulo: Brasiliense, 1990.

11. . Caminhos e fronteiras. São Paulo: Cia. das Letras, 1994.

12. KAYSER, B. A região como objeto de estudo da Geografia. In: GEORGE, P.; GUGLIEKMO, R.; KAYSER, B.; LACOSTE, Y. (orgs.). A geografia ativa. São Paulo: Difel/Edusp, pp. 279-321, 1968.

13. KOK, G. O sertão itinerante: expedições da capitania de São Paulo no século XVIII. São Paulo: Hucitec/Fapesp, 2004.

14. MAIA, J. M. E. A Terra como invenção - o espaço no pensamento social brasileiro. Rio de Janeiro: Jorge Zahar, 2008.

15. MARTINS, J. S. Capitalismo e tradicionalismo: estudos sobre as contradições da sociedade agrária no Brasil, São Paulo: Pioneira, 1975.

16. Fronteira: a degradação do outro nos confins do humano. São Paulo: Hucitec, 2009.

D

D D p.139-168, V.15, n.27, mai./ago. 2019. 
17. MELLO E SOUZA, L. Cotidiano e vida privada na América Portuguesa. In: NOVAIS, F. (dir.). A história da vida privada no Brasil. São Paulo: Cia. das Letras, 1997.

18. MONBEIG, P. Ensaios de geografia humana brasileira. São Paulo: Livraria Martins, 1940.

19. A divisão regional do estado de São Paulo. In: Anais da Associação dos Geógrafos Brasileiros (1945-1946). São Paulo: AGB, v. 1, 1949.

20. Pionniers et planteurs de l'État de São Paulo. Paris: Librarie Armand Colin, 1952.

21. O problema da divisão regional de São Paulo. In: Aspectos geográficos da Terra Bandeirante. Rio de Janeiro: Serviço Gráfico do I.B.G.E, 1954.

22. . Novos estudos de geografia humana brasileira. São Paulo: Difusão Européia do Livro, 1957.

23. Les franjes pionnières. Géographie générale, Encyclopédie de la Pléiade, Paris: Gallimard, pp. 974- 1005, 1966.

24. Pioneiros e fazendeiros de São Paulo. São Paulo: Hucitec, 1984.

25. MORAES, A. C. R. Território e história no Brasil. São Paulo: Hucitec, 2002.

26. Geografia histórica do Brasil - capitalismo, território e periferia. São Paulo: Annablume, 2011.

27. . Território na obra de Milton Santos. São Paulo: Annablume, 2013.

28. Geografia, interdisciplinaridade e metodologia. In: GEOUSP - Espaço e Tempo (online), São Paulo, v. 18, n. 1, 2014. Disponível em: http://www.journals.usp. br/geousp/article/view/81075/84723 Acesso em: 04 out. 2018.

29. NOGUEIRA, C. E. O lugar da fronteira na geografia de Pierre Monbeig. Tese (Doutorado em Geografia Humana) - DG/FFLCH/USP. São Paulo, 2013.

30. . A apropriação metodológica das frentes pioneiras na formação da geografia brasileira (1930-1950). In: Terra Brasilis (Nova Série), n. 5, 2015.

31. Disponível em: http://journals.openedition.org/terrabrasilis/1480. Acesso em: 24 out. 2018.

32. OLIVEIRA, L. L. Americanos: representações da identidade nacional no Brasil e nos EUA. Belo Horizonte: UFMG, 2000.

33. PRADO JR., C. Evolução política do Brasil e outros estudos. São Paulo: Brasiliense, 1953.

34. SALGUEIRO, H. A. (org.). Pierre Monbeig e a geografia humana brasileira - a dinâmica da transformação. Bauru: Edusc, 2006. 
35. SANTOS, M. Metamorfoses do espaço habitado. Fundamentos teóricos e metodológicos da Geografia. São Paulo: Hucitec, 1988.

36. . Pensando o espaço do homem. São Paulo: Hucitec, 1997.

37. A urbanização desigual: a especificidade do fenômeno urbano em países subdesenvolvidos. São Paulo: Edusp, 2010.

38. SMITH, N. Uneven development - nature, capital, and the production of space. Athens/ London: The University of Georgia Press, 2008.

39. SILVA, A. C. O espaço fora de lugar. São Paulo: Hucitec, 1978.

40. SILVA, L. O. A fronteira e outros mitos. Tese de concurso para Docente - DPHE/IE/ Unicamp, Campinas, 2001.

41. SOJA, E. Geografias pós-modernas: a reafirmação do espaço na teoria social crítica. Rio de Janeiro: Zahar, 1989.

42. SORRE, M. Les migrations des peuples. Paris: Flammarion, 1955.

43. VELHO, O. G. Frentes de expansão e estrutura agrária. Rio de Janeiro: Zahar, 1972. 44. . Capitalismo autoritário e campesinato. São Paulo: Difel, 1979.

45. WEGNER, R. A conquista do Oeste: a fronteira na obra de Sérgio Buarque de Holanda. Belo Horizonte: Ed. UFMG, 2000.

46. WOLF, D. Albert Demangeon (1872-1940). De l'école communale à la chaire en Sorbonne, l'itinéraire d'un géographe moderne. Paris: Université de Paris I, 2005. 